\title{
Late Carboniferous paleoelevation of the Variscan Belt: a stable isotope paleoaltimetry study in the French Massif Central
}

\author{
CAMILLE DUSSÉAUX ${ }^{1}$, AUDE GÉBELIN ${ }^{2}$, GILLES \\ RUFFET $^{3,4}$ AND ANDREAS MULCH ${ }^{5,6}$ \\ ${ }^{1}$ Université de Franche-Comté \\ ${ }^{2}$ SoGEES, University of Plymouth \\ ${ }^{3}$ CNRS (CNRS/INSU) UMR 6118 \\ ${ }^{4}$ Université de Rennes 1 \\ ${ }^{5}$ Senckenberg Biodiversity and Climate Research Centre (SBiK- \\ F) \\ ${ }^{6}$ Institute of Geosciences, Goethe University Frankfurt \\ Presenting Author: ca.dusseaux@gmail.com
}

We present the first stable isotope paleoaltimetry estimates for the hinterland of the eroded Variscan Belt of Western Europe based on the hydrogen isotope ratios of muscovite from syntectonic leucogranites that have been emplaced at $\sim 315$ Ma. We focus on the Limousin region (Western Massif Central, France) where peraluminous granites are spatially associated with strike-slip and detachment shear zones that developed as a consequence of Late Carboniferous syn- to post-orogenic extension and merge to the northwest with the South Armorican Shear Zone.

Here we show that the NE corner of the Millevaches massif located at the junction between brittle and ductile fault systems represented a pathway for Earth surface-derived fluids that penetrated the crust and reached the ductile segment of the lowangle Felletin detachment zone. Using microstructural, thermometry, hydrogen isotope geochemistry and ${ }^{40} \mathrm{Ar} /{ }^{39} \mathrm{Ar}$ geochronological data, we show that these Variscan meteoric fluids interacted with hydrous silicates during high temperature deformation between at least $\sim 318$ and $310 \mathrm{Ma}$.

For paleoaltimetry purposes, we reference our hydrogen isotope record $(\delta \mathrm{D})$ of ancient meteoric fluids from mylonitic rocks to 295 Myr-old records retrieved from freshwater shark remains preserved in the Bourbon l'Archambault basin that developed in the external zones of the orogen. A $\sim 76 \%$ difference in $\delta D_{\text {meteoric water values between the Millevaches }}$ massif $\left(\delta D_{\text {meteoric water }}\right.$ value $=-96 \pm 8 \%$ ) and the Bourbon l'Archambault foreland basin $\left(\delta \mathrm{D}_{\text {water }}\right.$ value $=-20 \pm 6 \%$ ) is consistent with minimum paleoaltimetry estimates of $3400 \pm 700$ $\mathrm{m}$ based on a modern lapse rate of $\sim-22 \% / \mathrm{km}$ for $\delta \mathrm{D}_{\text {water }}$ values. The rather large difference in $\delta \mathrm{D}$ values between the foreland basin and the continental interior suggests that the hinterland of the Variscan belt of western Europe was high enough to act as a barrier to moisture transport from the south-south-east and induce an orographic rain shadow to the north. 